\title{
The Impact of Water Level Decline on Water Quality in the Epilimnion of Lake Kinneret (Israel): Perennial Perspectives
}

\author{
M. Gophen ${ }^{1,2}$ \\ ${ }^{1}$ MIGAL-Scientific Research Institute, Kiryat Shmone, Israel \\ ${ }^{2}$ TEL-HAI Academic College, Kiryat Shmone, Israel \\ Email: Gophen@Migal.org.il
}

Received 7 September 2014; revised 7 October 2014; accepted 16 October 2014

Copyright (c) 2014 by author and Scientific Research Publishing Inc.

This work is licensed under the Creative Commons Attribution International License (CC BY). http://creativecommons.org/licenses/by/4.0/

CC) (i) Open Access

\begin{abstract}
Long term record (1933-2014) of Water Level (WL), nutrient concentrations, plankton densities, and temperatures in the epilimnion of Lake Kinneret was analyzed. The aim is to identify if water quality is deteriorated when the WL is low. It was found that water temperature increased and the composition and biomass of plankton communities were modified. Nitrogen and TDP decreased but TP slightly increased in the epilimnion during low WL conditions. The quality of epilimnetic water was not deteriorated and followed by a slight oligotrophism trend.
\end{abstract}

\section{Keywords}

Kinneret, Low Water Level, Plankton, Temperature, Epilimnion

\section{Introduction}

Lake Kinneret is the only natural freshwater lake in Israel located in the Syrian-African Rift Valley in northern Israel. The Israeli climate conditions are varied between desert in the south to subtropical in the north and mild Mediterranean in the center. Above 95\% of the Israeli natural water resources are utilized. Rain distribution over Israel (total $7.9 \mathrm{bcm} / \mathrm{y}$ ) varied between 1300 (north) < 100 (southern desert) mm/y: 70\% evapo-transpiration, 5\% runoffs, and $25 \%$ infiltration. Total national water supply is $2.11 \mathrm{bcm}\left(10^{9} \mathrm{~m}^{3}\right)$ of which $0.55 \mathrm{bcm}$ from the Kinneret-Jordan system and $0.7 \mathrm{bcm}$ from desalination sources. Thirty percent $(0.750 \mathrm{bcm} / \mathrm{y})$ of supplied water is given as drinking qualities for housing consumption. The only open options to enhance water resources are desalination and recycling. Averaged water budget for Lake Kinneret is given in Table 1 [1]).

Lake Kinneret was designed as major source of drinking water supply. In 1933 the south end of the lake was 
Table 1. Annual water budget (million cubic meters [mcm] per year) of Lake Kinneret (Gvirzman, 2002).

\begin{tabular}{cc}
\hline Input & \\
\hline River Jordan & 480 \\
Golan Heights Rivers & 145 \\
Direct rain & 75 \\
Eastern Galilee & 75 \\
Diversion from Jarmuch & 25 \\
Total input & 800 \\
\hline Output & 280 \\
\hline Evaporation & 380 \\
National Water Carrier & 80 \\
To South Jordan via Dam & 60 \\
Local consumers & 800 \\
Total output &
\end{tabular}

blocked by a dam. From that time the outflow is controlled by lake management policy which is limited by hydrological, national regulations, management design and environmental constrains. Recently, desalinated water replaces most of the Kinneret resources. The National Water Carrier (NWC) was constructed during the 1950s (operated 10.6.1964). During the last 49 years the NWC system withdrew approximately $15 \mathrm{bcm}$ of water from the lake (ca 3.8 times the lake volume) for drinking, agriculture, industry and aquifer recharging. Nevertheless, as a result of water level restriction management, about $4 \mathrm{bcm}$ of water were released through the south dam to the Dead Sea. Lake water salinity is highly fluctuated: 300 - 330 ppm chloride before 1960, 400 ppm during early 1960s and 200 - 210 ppm during early 1980s and then gradually increased to $280-300$ ppm in 2002. Lake kineret became a significant supplier of salts to the Israeli soils and aquifers. About 9 million tons of dissolved salty ions $\left(\mathrm{Cl}, \mathrm{CO}_{3}, \mathrm{Na}, \mathrm{Mg}, \mathrm{K}, \mathrm{Ca}, \mathrm{SO}_{4}\right)$ deteriorate soils and aquifer qualities in the southern part of Israel.

\section{Regional Hydrology}

Three major rivers (Hatzbani, Banyas and Dan) flow from the Hermon mountain region, located in the north part of the Kinneret drainage basin. These rivers joint into one river of Jordan which is crossing the Hula Valley through two major man-made canals: $80 \%$ and $20 \%$ of the Jordan water flow via the eastern and western canals respectively. In the south end of the valley the two canals joint into one water flow, the Jordan route flowing downstream into Lake Kinneret. Hula Valley altitude is between 170 - 61 m above sea level and Lake Kinneret WL is fluctuated between 208.80 - $214.87 \mathrm{~m}$ below sea level. The upper and lower WL legislation was highly discussed over the years. The upper limit (red line) was decided as -208.8 and was never changed. The background for that regulation was due to existed housing distance from shoreline and predicted compensations resulted by potential damage. The lower limit was mostly due to limnological trait and predicted impact on water quality. Because of the flexibility of this issue and water supply vs rain gauge (drought) constrains, the lower limit was changed several times. The constrains of water supply during drought forced to lower the bottom limit which was therefore changed several times: $-212,-213$, and -215 . The cardinal dispute that is never clearly settled is therefore: How low can WL be? The Jordan river contributes about $63 \%$ of the Kinneret water budget and more than $50 \%$ of total external nutrient inputs of the total originate in the Hula Valley Region. The drainage basin area of Lake Kinneret is $2730 \mathrm{~km}^{2}$, located mostly northern to the lake of which "Hula Valley" is about $200 \mathrm{~km}^{2}$. From 1972 the hydrological management of the Kinneret-River Jordan system was controlled by both rain gauge and the "NWC management". NCW management included maximum close dam that was aimed at maximum storage and national supply by pumping through the "carrier". It is likely that close dam policy might be disadvantageous. Before Dam construction nutrient rich winter input floods crossed the lake in upper layers resulted by their higher temperature than that of the epilimnetic water and naturally left out through the open outlet. 
Close dam management enhanced nutrient retaining in the hypolimnion and the sediments. Water withdrawal was done by daily pumping from upper layers. In comparison with "no dam” condition, “close dam” management might enhance nutrients accumulation. Moreover, winter demands for supply are lower than in summer, therefore additional nutrients retaining in the lake sediments is predicted because in winter nutrient concentrations are higher. Nevertheless, when lakes are comparatively analyzed it has to be considered that in Lake Konstanz for example only 1\% of the input is pumped and no Dam construction whilst in lake Kinneret app. 60\% of the total inputs were pumped prior to the desalination period. Moreover, water retention time is very significant parameter. In Lake Kinneret this value is 5.6 years when maximum permitted WL (208.8 m below sea level) is maintained.

The Kinneret ecosystem has undergone significant changes during the last 70 years. Some of the changes are natural like droughts and floods, and others are anthropogenic like land-use in the drainage basin or fishery and salts diversion in the lake. Increasing population up to above 200,000 inhabitants in the drainage basin, sewage removal and fishpond restriction in the catchment, operating new agricultural technologies (crop types, irrigation) and development of eco-tourism [2]-[4]. The Lake Kinneret water quality is of a national concern therefore the lake is depends on the nation and the nation is depends on the lake [2] [3]. The lake supplies 16\% - 30\% of the national water demands and $>55 \%$ of drinking water requirements. Kinneret is a warm monomictic lake which is stratified from May through mid December (anoxic hypolimnion) and totally mixed during mid December through April. Among fluctuations of lake conditions are high (6.3 m) amplitude of water level (208.57 - 214.87 mbsl); high inflow discharges $\left(>10^{9} \mathrm{~m}^{3}\right.$ per annum) and droughts $\left(<260 \times 10^{6} \mathrm{~m}^{3}\right.$ per annum); low (333 mm/y) and high $(1060 \mathrm{~mm} / \mathrm{y})$ precipitations in the drainage area; plankton biomass and composition changes, fish stocks, epilimnetic temperatures and nutrient concentrations. The seasonal pattern of the distribution of hydrological, chemical and biological parameters consistently represents subtropical climate conditions: high levels in winter and low in summer months but high hypolimnetic inventories of dissolved phosphorus, ammonium, sulfides and $\mathrm{CO}_{2}$ in summer-fall period as a result of the thermal and chemical stratification.

The lake is exploited for its fishing by ca 200 licensed fishermen which remove commercially an average of 1600 ton of fish (94 kg/ha) per annum. The zooplanktivorous Lavnun (bleak, Acanthobrama spp.) comprised 55\% by weight of total catches and $>50 \%$ of the stock biomass. Among 8 commercial species out of 24 recorded the native Tilapias (averaged $326 \mathrm{t}$ /year) and the exotic Mugil (averaged $160 \mathrm{t}$ /year) are the most important in the commercial landings [2] [3]. This paper is aimed at contributing answer and verifications to the question: How low can WL of Lake Kinneret be? The issue is limited between two extremely unchangeable constrains: the -208.8 upper WL limit and the lowest possible WL -215.00 as constrained by technical operational option of the intake of the NWC.

\section{Methods}

Data of temperatures, nutrient concentrations and plankton densities in the epilimnion, were taken from the Lake Kinneret Data Base ([5] of the Kinneret Limnological Laboratory which are reported annually (1970-2014). The data of the Jordan River nutrient loads, and concentrations and discharge were taken from the annual and temporal reports published by The National Water Company of MEKOROT. Eighty years of daily WL record (TAHAL-Water Planning of Israel, MEKOROT-Israel Water Supply Company, Kinneret Limnological Laboratory) were breaking down by two ways: 1) The entire period of post Dam construction (1933-2014) was divided into four groups of 20 years each: 1 = 1933-1953; 2 = 1954-1973; 3 = 1974-1993; 4 = 1994-2014; and 2) Post operation of the NWC (1965-2014) by two groups of 24 years each: 1 = 1965-1989; 2 = 1990-2014; The whole record contain monthly averages of daily measured WL. The WL of the four temporal groups (20 years each) was comparatively analyzed by ANOVA test $(p<0.05)$, and results are presented in Table 2 . Further analysis of the nutrient and plankton concentrations in the epilimnion was referred comparatively to these 4 periods.

Statistical analyses used in this study were taken from STATA 9.1, Statistics-Data Analysis and Stat View 5.1, SAS Institute Inc. The analyses used were: ANOVA $(p<0.05)$, polynomial and linear regressions, fractional polynomial prediction, LOWESS (0.8). These statistical evaluations were used in two ways: 1) Regressions between each parameter and its monitored orderly decline respected WL values. Results are presented in figures; 2) Analysis between periodical (years) groups by comparative evaluation of the parameters (plankton, nutrients, etc.) in that time frame. The WL values were also included in the analysis to enable consideration of WL impact. Results are presented in tables. 
Table 2. Comparative analysis (ANOVA test; $p<0.05$ ) of WL between 4 twenty year groups. $\mathrm{S}=$ significant; $\mathrm{NS}=$ not significant.

\begin{tabular}{ccccc}
\hline Number & Period & Average WL (mbsl) & Relative scale (high $>$ low) & Probability $(\boldsymbol{p})$ \\
\hline 1 & $1933-1953$ & -210.55 & $1<2$ & $<0.0001 \mathrm{~S}$ \\
2 & $1954-1973$ & -209.77 & $1<3$ & $0.1069 \mathrm{NS}$ \\
3 & $1974-1993$ & -210.39 & $1>4$ & $<0.0001 \mathrm{~S}$ \\
4 & $1994-2013$ & -211.84 & $2>3$ & $<0.0001 \mathrm{~S}$ \\
& & $2>4$ & $<0.0001 \mathrm{~S}$ \\
& & $3>4$ & $<0.0001 \mathrm{~S}$ \\
\hline
\end{tabular}

\section{Results}

The period after the construction of the south Dam, (1933-2014) or the period later than the operation of the NWC (1965-2014) were considered and divided differently: the first divided into 4 groups of 20 years each. The second period was divided into two groups, 24 years each. The two methods indicate clearly low WL later than 1990. The paper is focused on comparative analysis of the epilimnetic water quality and temperature aimed at an attempt to identify long term impact of low WL. The formal daily monitoring of WL in Lake Kinneret WL started in 1926. The precision of WL information prior to 1931 is doubtful. Therefore these data will not be considered. Measurements of the Jordan outlet threshold bottom indicated an altitude of -212.35 mbsl and WL data consequently indicate water depths at the Jordan outlet of $4 \mathrm{~m}$ and $2 \mathrm{~m}$ in winter and summer respectively (Figure 1). Reports and photos from late 1920s and early 1930s evidently show people, and horses pulling wagons crossing this river section by foot. Consequently the period of 1926-1933 is neglected in this paper. The WL of Lake Kinneret was prominently lower during 1994-2013 (Table 2). WL during period 3 (1974-1993) was lower than period no. 2 (Table 2). Lake conditions after 1994 are titled as "low level period”. When post NWC operation period, 1965-2014, is considered, two distinct periods were indicated: High WL in 1965-1989 and Low WL in 1990-2014 which is similar to the previous classification. WL was averaged as 210.05 mbsl (SD $0.84 \mathrm{~m}$ ) during 1965-1989, and 211.65 mbsl (SD = $1.55 \mathrm{~m}$ ) during 1990-2014. Averaged WL during the first period was higher than that of the second period by $1.6 \mathrm{~m}$ with lower amplitude and fluctuations frequency than during 1990-2014 expressed as higher SD’s. WL fluctuations during 1926-2014 (Figure 2). It is prominent that before the NWC operation (1964) Wl was consistently high with small amplitude of seasonal changes than after the NWC operation when demands for domestic supply intensified and droughts became more frequent. Results given in Figure 3 obviously confirm the direct relation between Jordan River discharge and the Kinneret WL. Data shown in Tables 3-7 and Figures 4-6 identify a trend of oligotrophism in the epilimnion of Lake Kinneret later than early 1990s. It is expressed by the decline of Nitrogen compounds and dissolved Phosphorus. Nevertheless TP not only did not declined but slightly increased. Those trends of $\mathrm{N}$ and $\mathrm{P}$ changes initiated conditions which are in favor by $\mathrm{N}_{2}$ fixers Cyano-bacteria but causing reduction of the $\mathrm{N}$ required alga, the Peridinium. Figures 7-12 and Table 5, Table 6 confirm decline of herbivorous and increase of predator zooplankton accompanied by decreasing biomass of Phytoplankton when WL was low. Independently with trophic conditions, epilimnetic temperature increased when WL decline (Figure 12). Lower WL is primarily the result of lower rain gauge and consequently lower river discharge (Figure 3) but also due to higher pumping regime (resulted by demands elevations). Lower discharge is obviously accompanied by lowering of external load inputs of nutrients which significantly enhance oligotrophism. Direct relations $\left(r^{2}\right.$ range $0.596-0.886$, probabilities $\left.<0.0001\right)$ were documented between Jordan River discharge and monthly load inputs of nutrients (TN, TP, TIN, Sulfate, Chloride and Organic Nitrogen). Results in Table 3 indicate significant direct relations between epilimnetic nutrient (except TP) concentrations and WL: the lower the WL is, the lower is also the nutrient concentration in the epilimnion. Moreover, the lower the River Jordan discharge is, the lower is also the nutrient concentration in its input water. Statistical analysis (linear regression) between annual landings of Tilapias and total native fish did not indicate significant relations (data is not shown here). Results presented in Tables 3-6, where nutrients and zooplankton conditions are comparatively analyzed, prominently indicates that the periods with low WL are characterized by low values. Figure 3 clarify the impact of Low WL (started in early 1990s), when Jordan river 


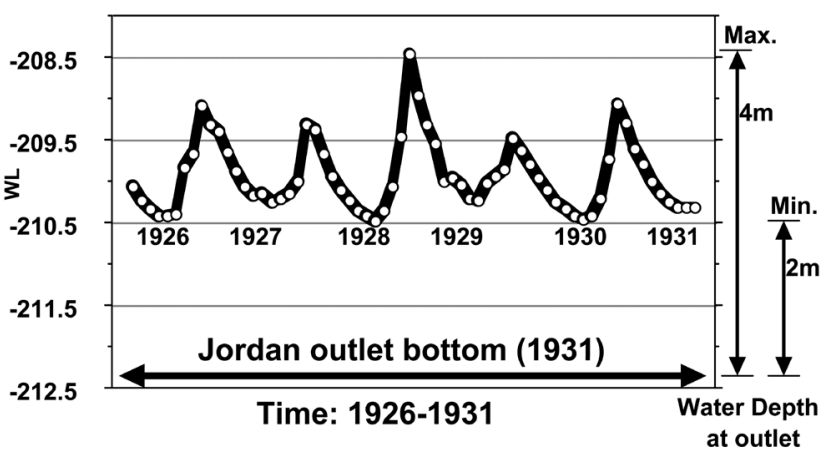

Figure 1. Kinneret WL fluctuations (monthly means) during 1926-1931 before Dam constructions. Respective water depth at the Jordan outlet point are given.

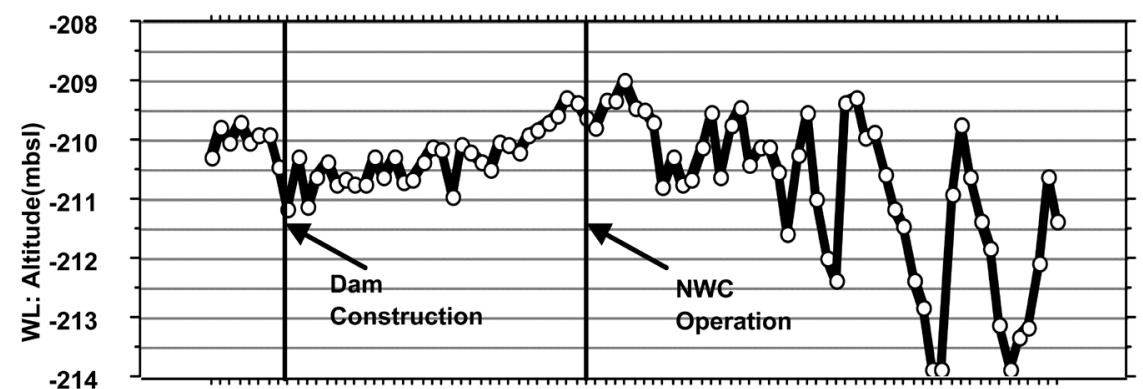

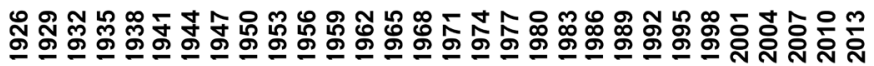

Figure 2. Kinneret WL fluctuations (monthly means) during 1926-2014. Timing of Dam constructions and NWC operation are indicated.

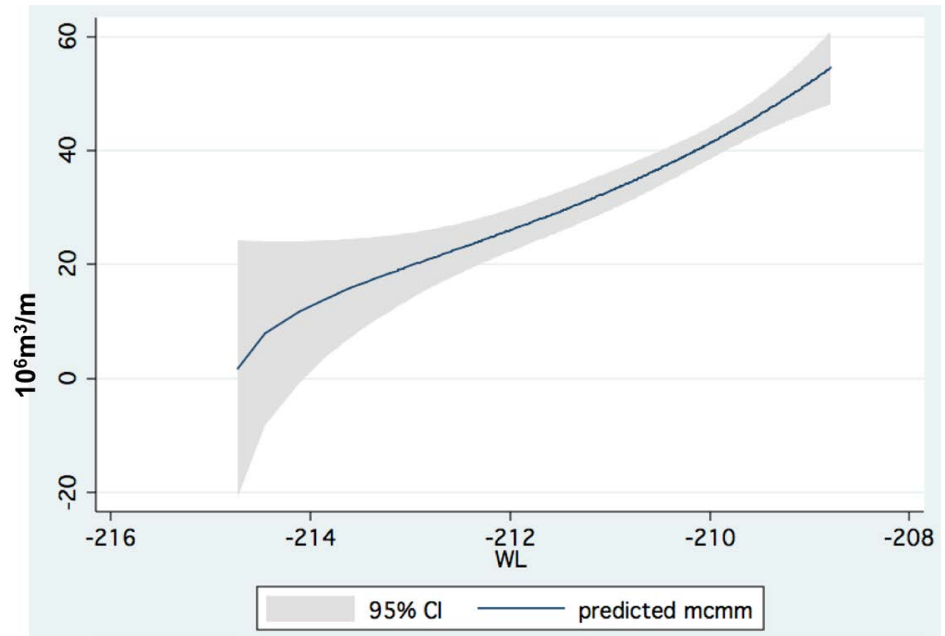

Figure 3. Fractional polynomial prediction (95\% CI) of Jordan monthly discharge $\left(10^{6} \mathrm{~m}^{3}\right.$; mcmm) vs. Kinneret WL (monthly means).

discharge was reduced on the concentrations of TN, TIN, TDP, zooplankton (all groups, herbivorous and predator), pyrrhophyta biomass in the epilimnion of Lake Kinneret (Figures 4-11).

\section{Discussion}

$\mathrm{Wl}$ decline in Lake Kinneret is mostly resulted by rain reduction and partly by water supply (pumping) regime. The major outcomes of the Kinneret WL decline were primarily changes of nutrients dynamic and consequently 
Table 3. Polynomial regressions between nutrient concentrations (ppm) and pyrrhophyta biomass $\left(\mathrm{g} / \mathrm{m}^{2}\right)$ averaged for the epilimnion vs. WL (upper part) and Jordan discharge $(\mathrm{mcm} / \mathrm{m})$ (lower part). All regressions except TP indicate direct positive relations with WL: decline with lowering WL. Parameters of $r^{2}$, $p$ = significance level, $\mathrm{S}=$ significant, are given.

\begin{tabular}{|c|c|c|c|}
\hline Nutrient & $r^{2}$ & $p$ & Significance \\
\hline \multicolumn{4}{|l|}{ Lake WL } \\
\hline PON & 0.126 & $<0.0001$ & S \\
\hline TIN & 0.086 & $<0.0001$ & S \\
\hline Kieldhal total & 0.085 & $<0.0001$ & S \\
\hline TDN & 0.130 & $<0.0001$ & S \\
\hline TDP & 0.090 & $<0.0001$ & $S$ \\
\hline $\mathrm{TP}$ & 0.010 & 0.1359 & NS \\
\hline Pyrrhophyta & 0.127 & $<0.0001$ & S \\
\hline $\mathrm{TN}$ & 0.187 & $<0.0001$ & S \\
\hline \multicolumn{4}{|c|}{ Jordan disch. (mcm/m) } \\
\hline PON & 0.098 & $<0.0001$ & S \\
\hline TIN & 0.558 & $<0.0001$ & $S$ \\
\hline Kieldhal total & 0.099 & $<0.0001$ & $S$ \\
\hline TDN & 0.368 & $<0.0001$ & S \\
\hline TDP & 0.079 & $<0.0001$ & S \\
\hline TP & 0.208 & $<0.0001$ & S \\
\hline Pyrrhophyta & 0.135 & $<0.0001$ & S \\
\hline $\mathrm{TN}$ & 0.339 & $<0.0001$ & S \\
\hline
\end{tabular}

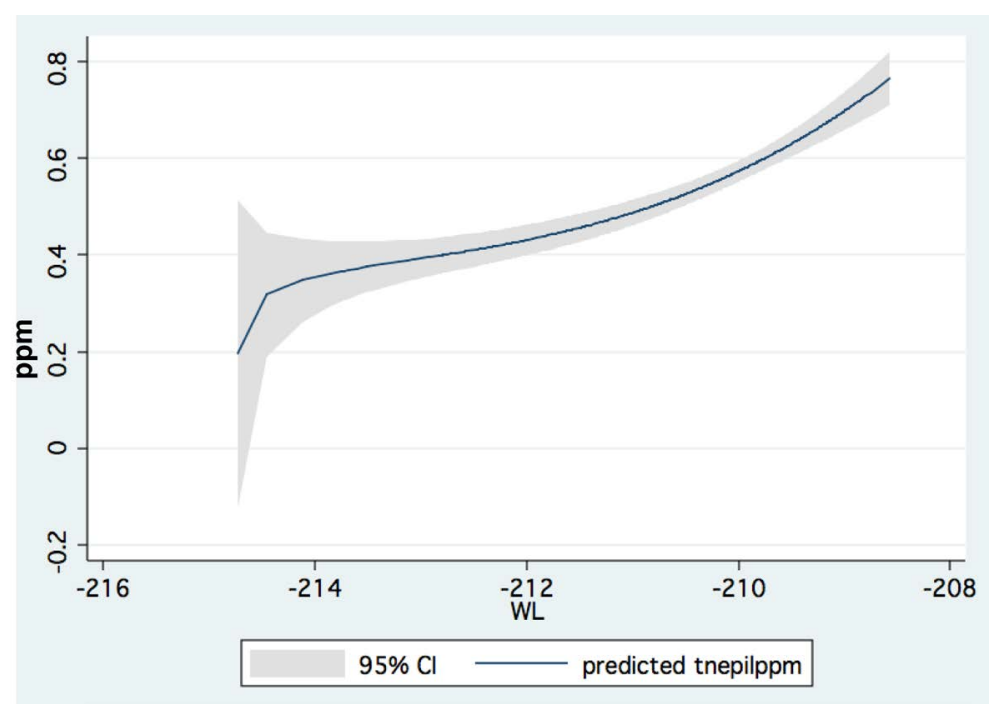

Figure 4. Fractional polynomial prediction (95\% CI) of epilimnetic TN concentration (ppm; TN-epilimnion-ppm) vs. Kinneret WL (monthly means). 
Table 4. Results of ANOVA Test $(p<0.05)$ comparative analysis between monthly means of zooplankton biomass $\left(\mathrm{g} / \mathrm{m}^{2}\right)$ in three periods $(2=1954-1973 ; 3=1974-1993$; 4 = 1994-2013). Significance levels $(p)$, indications ( $\mathrm{S}=$ significant; NS = not significant) and scaled levels (higher > lower) are given.

\begin{tabular}{|cccc}
\hline \multicolumn{5}{c}{ Total zooplankton } & \\
\hline Periodical mean WL (mbsl) & Periodical average $\left(\mathbf{g} / \mathbf{m}^{2}\right)$ & Relative scale & Significance $(\boldsymbol{p})$ \\
\hline $2(-209.77)$ & 41.4 & $2>3$ & $<0.0001 \mathrm{~S}$ \\
$3(-210.39)$ & 25.7 & $2>4$ & $<0.0001 \mathrm{~S}$ \\
$4(-211.84)$ & 29.9 & $3<4$ & $0.0079 \mathrm{~S}$ \\
\hline $2(-209.77)$ & Cladocera & & \\
$3(-210.39)$ & 23.4 & $2>3$ & $<0.0001 \mathrm{~S}$ \\
$4(-211.84)$ & 15.2 & $2>4$ & $0.0032 \mathrm{~S}$ \\
\hline $3(-209.77)$ & 18.3 & $3<4$ & $0.0102 \mathrm{~S}$ \\
\hline $3(-210.39)$ & Copepoda & & $<0.0001 \mathrm{~S}$ \\
$4(-211.84)$ & 14.9 & $2>3$ & $<0.0001 \mathrm{~S}$ \\
\hline $3(-210.39)$ & 8.7 & $2>4$ & $0.2255 \mathrm{NS}$ \\
\hline $2(-209.77)$ & 9.5 & $3<4$ & $0.0445 \mathrm{NS}$ \\
\hline
\end{tabular}

Table 5. Results of ANOVA test $(p<0.05)$ comparative analysis between monthly means of the biomass $\left(\mathrm{g} / \mathrm{m}^{2}\right)$ of zooplankton feeding behavior groups in three periods ( 2 = 1954-1973; 3 = 1974-1993; 4 = 1994-2013). Significance levels $(p)$, indications ( $\mathrm{S}$ = significant; NS = not significant) and scaled levels (higher $>$ lower) are given .

\begin{tabular}{|cccc}
\hline \multicolumn{4}{c}{ Herbivorous zooplankton } \\
\hline Periodical mean WL (mbsl) & Periodical average $\left(\mathbf{g} / \mathbf{m}^{2}\right)$ & Relative scale & Significance $(\boldsymbol{p})$ \\
\hline $2(-209.77)$ & 32.0 & $2>3$ & $<0.0001 \mathrm{~S}$ \\
$3(-210.39)$ & 20.3 & $2>4$ & $<0.0001 \mathrm{~S}$ \\
$4(-211.84)$ & 23.9 & $3<4$ & $p=0.0084 \mathrm{~S}$ \\
\hline $2(-209.77)$ & Herbivorous copepoda & & \\
$3(-210.39)$ & 5.5 & $2>3$ & $<0.0001 \mathrm{~S}$ \\
$4(-211.84)$ & 3.2 & $2>4$ & $<0.0001 \mathrm{~S}$ \\
& 3.5 & & $p=0.2230 \mathrm{NS}$ \\
\hline $2(-209.77)$ & Predator copepoda & $2>3$ & $<0.0001 \mathrm{~S}$ \\
$3(-210.39)$ & 9.4 & $2>4$ & $<0.0001 \mathrm{~S}$ \\
$4(-211.84)$ & 5.5 & $3<4$ & $p=0.2230 \mathrm{NS}$ \\
\hline
\end{tabular}


Table 6. Results of ANOVA test $(p<0.05)$ comparative analysis between monthly means of the epilimnetic mean nutrient concentrations (ppm) in three periods (2 = 1954-1973; 3 = 1974-1993; 4 = 1994-2013). Significance levels $(p)$, indications (S = significant; NS = not significant) and scaled levels (higher $>$ lower) are given.

\begin{tabular}{|c|c|c|c|}
\hline \multicolumn{4}{|c|}{ TN (ppm) } \\
\hline Periodical mean WL (mbsl) & Mean concentration (ppm) & Relative scale & Significance $(p)$ \\
\hline $2(-209.77)$ & 0.568 & & \\
\hline $3(-210.39)$ & 0.582 & $4<3$ & $<0.0001 \mathrm{~S}$ \\
\hline $4(-211.84)$ & 0.439 & $4<2$ & $p=0.0005 \mathrm{~S}$ \\
\hline \multicolumn{4}{|c|}{ TP (ppm) } \\
\hline $2(-209.77)$ & 0.013 & & \\
\hline $3(-210.39)$ & 0.017 & $2<3$ & $<0.0001 \mathrm{~S}$ \\
\hline $4(-211.84)$ & 0.017 & $2<4$ & $<0.0001 \mathrm{~S}$ \\
\hline \multicolumn{4}{|c|}{ TIN (ppm) } \\
\hline $2(-209.77)$ & 0.160 & & \\
\hline $3(-210.39)$ & 0.150 & $4<2$ & $p=0.0294 \mathrm{~S}$ \\
\hline $4(-211.84)$ & $0 / 115$ & $4<3$ & $p=0.0220 \mathrm{~S}$ \\
\hline \multicolumn{4}{|c|}{ TDN (ppm) } \\
\hline $2(-209.77)$ & 0.368 & & \\
\hline $3(-210.39)$ & 0.431 & & \\
\hline $4(-211.84)$ & 0.321 & $4<3$ & $<0.0001 \mathrm{~S}$ \\
\hline \multicolumn{4}{|c|}{ TDP } \\
\hline $2(-209.77)$ & No data & & \\
\hline $3(-210.39)$ & 0.008 & & \\
\hline $4(-211.84)$ & 0.006 & $4<6$ & $<0.0001 \mathrm{~S}$ \\
\hline
\end{tabular}

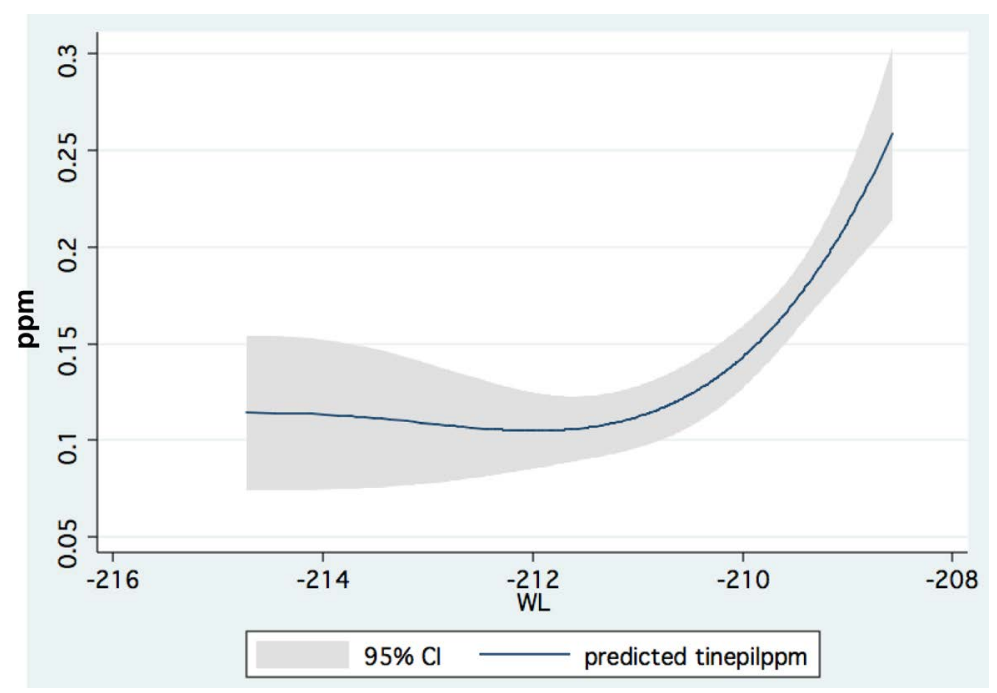

Figure 5. Fractional polynomial prediction (95\% CI) of epilimnetic TIN concentration (ppm; TIN-epilimnion-ppm) vs. Kinneret WL (monthly means). 
Table 7. Metabolic parameters of zooplankton in Lake Kinneret. Herbivorous copepods are young life stages and predator stages are adults and copepodites 4 and 5. Values are given in mgC/body mgC/day [9].

\begin{tabular}{cccccc}
\hline Zooplankters & $\begin{array}{c}\text { Temper. } \\
\left({ }^{\circ} \mathbf{C}\right)\end{array}$ & $\begin{array}{c}\text { Production } \\
(\mathbf{m g C} / \mathbf{m g C} / \mathbf{d a y})\end{array}$ & $\begin{array}{c}\text { Respiration } \\
(\mathbf{m g C} / \mathbf{m g C} / \mathbf{d a y})\end{array}$ & $\begin{array}{c}\text { Consumption } \\
(\mathbf{m g C} / \mathbf{m g C} / \mathbf{d a y})\end{array}$ & Efficiency (\%) \\
\hline Hebivorous copepods & 15 & 0.050 & 0.288 & 0.750 & 45 \\
Hebivorous copepods & 20 & 0.113 & 0.550 & 2.750 & 24 \\
Hebivorous copepods & 27 & 0.167 & 1.125 & 3.250 & 39 \\
Predator copepods & 15 & 0.048 & 0.163 & 0.465 & 45 \\
Predator copepods & 20 & 0.103 & 0.287 & 2.142 & 18 \\
Predator copepods & 27 & 0.160 & 0.499 & 2.517 & 26 \\
Cladocera & 15 & 0.140 & 0.153 & 1.200 & 24 \\
Cladocera & 20 & 0.160 & 0.190 & 2.750 & 13 \\
Cladocera & 27 & 0.210 & 0.413 & 4.650 & 13 \\
Rotifera & 15 & 0.047 & 0.153 & 0.750 & 27 \\
Rotifera & 20 & 0.080 & 0.190 & 2.375 & 11 \\
\hline
\end{tabular}

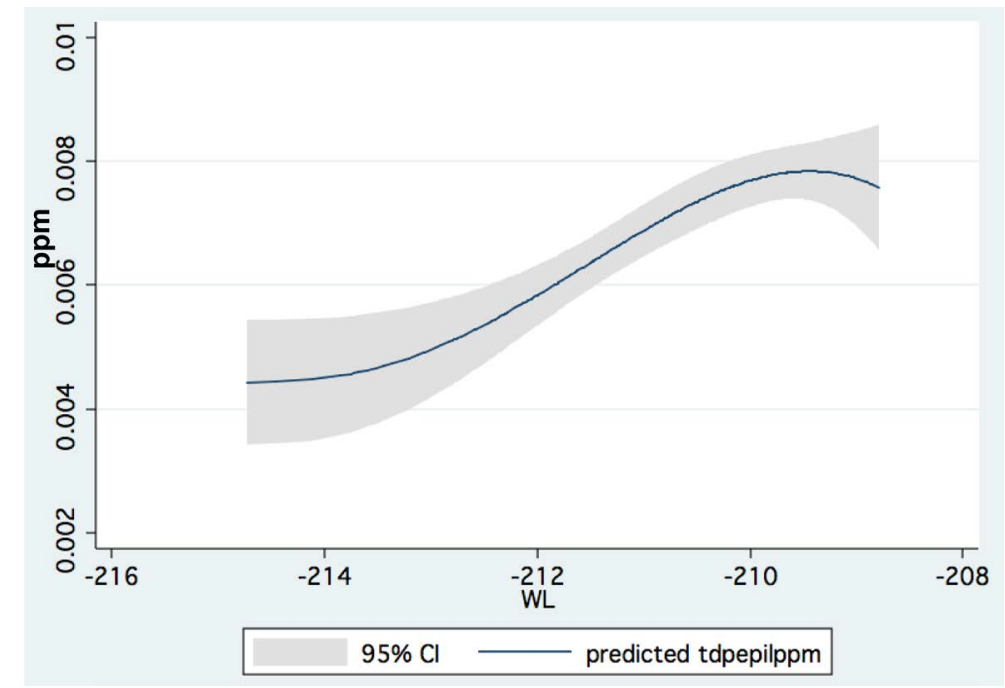

Figure 6. Fractional polynomial prediction (95\% CI) of epilimnetic TDP concentration (ppm; TDP-epilimnion-ppm) vs. Kinneret WL (monthly means).

modification of phytoplankton community structure and biomass. Other effects were modifications of zooplankton population composition and biomass densities. Fish stocks changes as reflected by annual landings were insignificantly correlated with WL Studies of the impact of WL decline on the limnological conditions of lakes commonly include examples of extreme cases like Lake Chad, Aral Sea and Lake Sivan. These kind of comparative consideration as well as those with man-made reservoirs should be carefully evaluated. Moreover, even if WL fluctuations are moderate in lakes under different anthropogenic operational management the system response might be different. WL decline in Lake Kinneret varied mostly within the maximum amplitude of 6 meters and the Kinneret is a deep lake with Max. and mean depths of $45 \mathrm{~m}$ and $26 \mathrm{~m}$ respectively. The lowest WL permitted in Lake Kinneret is limited to the depth of the intake of the NWC (215 m mbsl) and the upper limit is legislated to 208.8 mbsl. About 55\% of water inputs in Lake Kinneret are pumped for human consumption. The comparison of WL decline conditions between two lake ecosystems which have different type of Hypsometric curve are misleading. The shoreline length of Lake Kinneret is $53 \mathrm{~km}$ and the Value of the Development of 


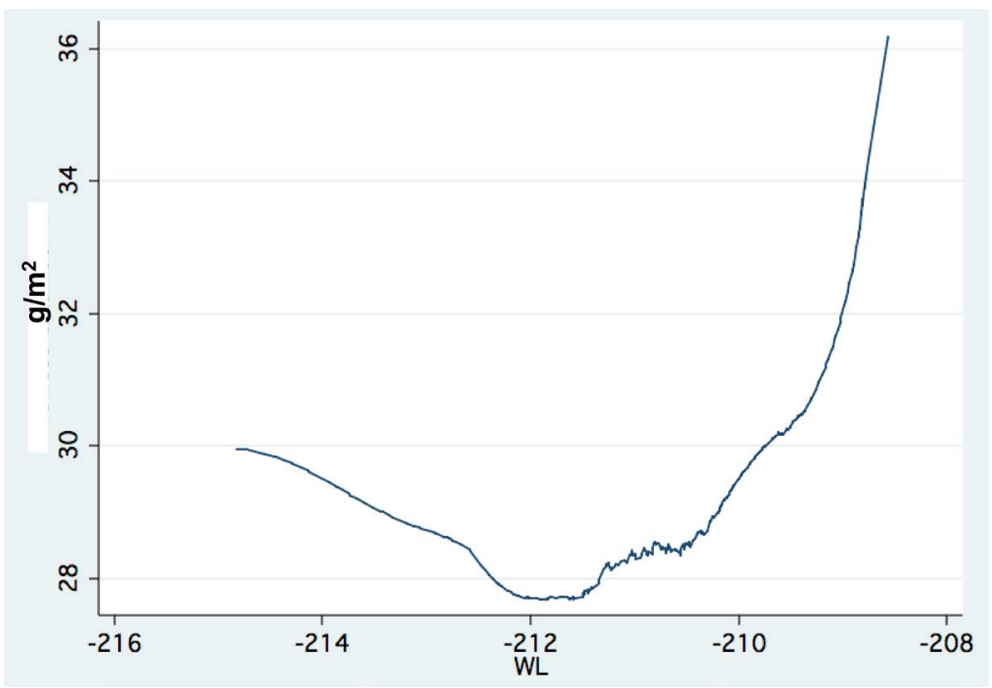

Figure 7. Trend of changes (LOWESS) of total zooplankton biomass $\left(\mathrm{g} / \mathrm{m}^{2}\right) \mathrm{vs}$. Kinneret WL (monthly means).

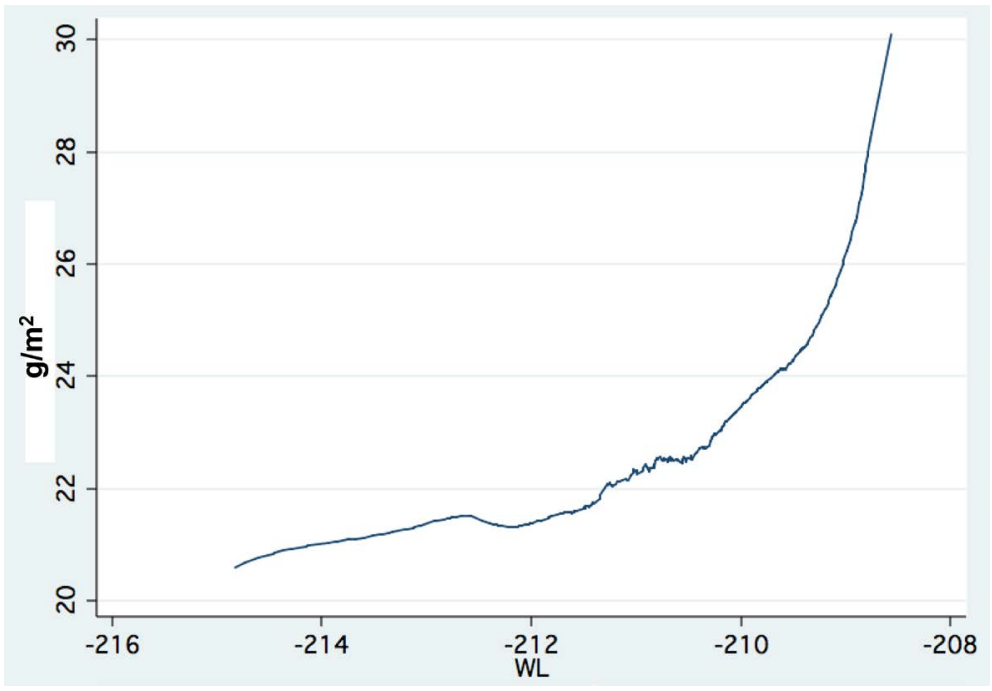

Figure 8. Trend of changes (LOWESS) of herbivorous zooplankton biomass $\left(\mathrm{g} \cdot \mathrm{m}^{2}\right)$ vs. Kinneret WL (monthly means).

Shoreline is 1.16 and residence time is 5.6 years. Therefore comparative study of WL decline in Lake Kinneret with shallow lakes or very deep lakes, with different residence time, thermal structure (amictic, monomictic or polymictic), the amplitude range of the WL change, and others, are mostly irrelevant due to significant differ of limnological conditions between those ecosystems. Human population (and sewage production) and pollutant inputs are significant parameters involved. In Lake Konstanz (Germany-Austria-Swiss) population density in the vicinity of the lake is app. 4170 whilst in Lake Kinneret 950 residents per $1 \mathrm{~km}$ of shoreline, respectively, or, 19,500 residents and 12,500 capita per $1 \mathrm{~km}^{3}$ of lake water in Konstanz and Kinneret respectively. In Lake Sivan in Armenia, WL was lowered by 19 meters, whilst in Lake Kinneret only maximum of $6 \mathrm{~m}$ but usually about $1.5-2.0 \mathrm{~m}$. The shallow lakes of Aral Sea and Lake Chad were dried as a result of extreme WL decline whilst in Lake Kinneret only $10.3 \mathrm{~km}^{2}$ are exposed when WL decline from maximum to minimum permitted (208.8 - 214 mbsl). WL decline in lake Chad caused water surface reduction of $12,000 \mathrm{~km}^{2}(48 \%)$ due to climate change and increased water consumption. In the Aral Sea $70 \%$ of the water inflows were diverted for agriculture and WL declined by 15 meters. Neither Chad, and Aral nor Sivan lake are dissimilar ecosystems to Lake Kinneret and comparison is misleading. 


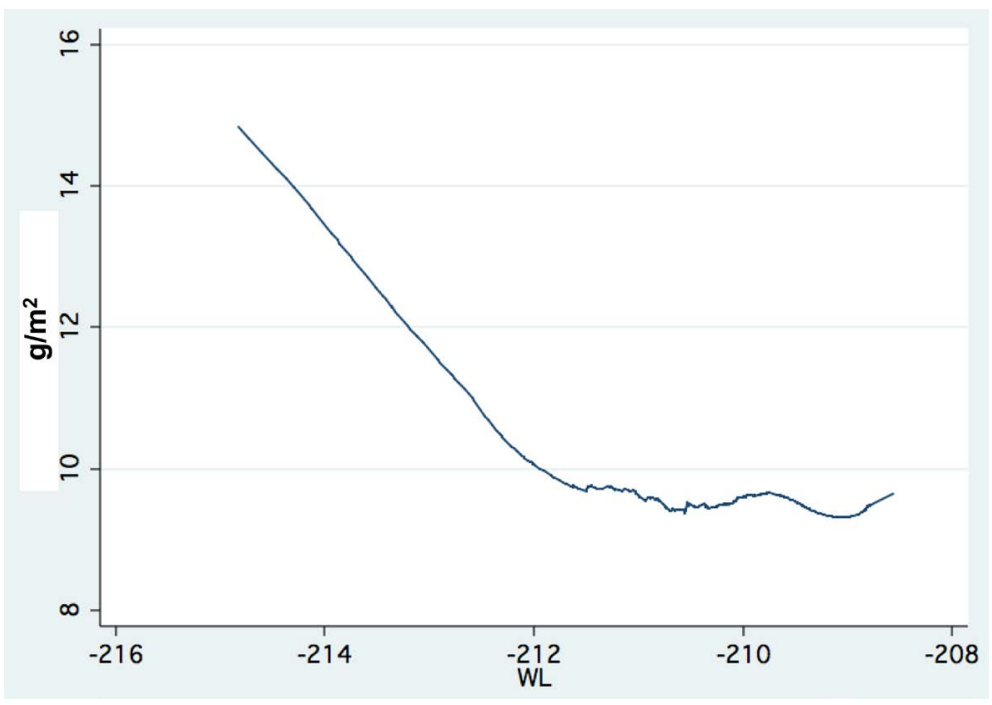

Figure 9. Trend of changes (LOWESS) of copepoda biomass $\left(\mathrm{g} \cdot \mathrm{m}^{2}\right)$ vs. Kinneret WL (monthly means).

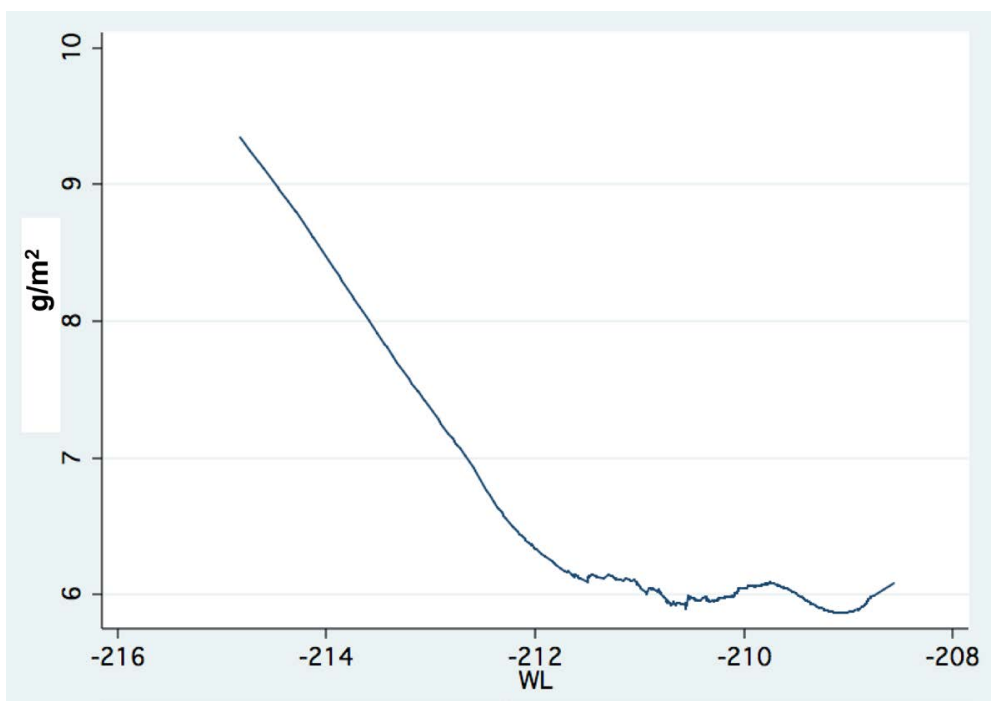

Figure 10. Trend of changes (LOWESS) of predator copepods biomass $\left(\mathrm{g} \cdot \mathrm{m}^{2}\right)$ vs. Kinneret WL (monthly means).

\subsection{Epilimnetic Temperatures}

Epilimnetic temperatures data indicates cooling trend of Kinneret water during 1970-mid 1980s when WL was more or less consistently high. Epilimnetic lake water warming (by $1.8^{\circ} \mathrm{C}$ ) documented afterwards during WL decline. During WL decline the temperature of the thermocline increased and its depth was reduced (shallower) with consequent reduction of the volume of the epilimnion. Warmer epilimnion, shallower and warmer thermocline indicates elevation of epilimnetic specific Heat capacity $\left(\mathrm{cal} / \mathrm{m}^{3}\right)$. It is in agreement with intensification of light absorbance expressed as shallower Secchi depth, due to enhancement of the density of small particles (nano-phytoplankton). The shift of phytoplankton composition from large cells Peridinium to small sized algae with higher particle density probably enhanced heat capacity in the epilimnion. The implication of the warming process might have an impact on the lake metabolism: enhancement of biological, microbiological, chemical and obviously physical rate of processes. A parameter which contributed to the warming process of the epilimnion under regime of WL decline is the Albedo factor. Temporal changes of the epilimnetic and $3 \mathrm{~m}$ above water surface (Figure 12) temperatures in Lake Kinneret were documented. These fluctuations are similar to the 


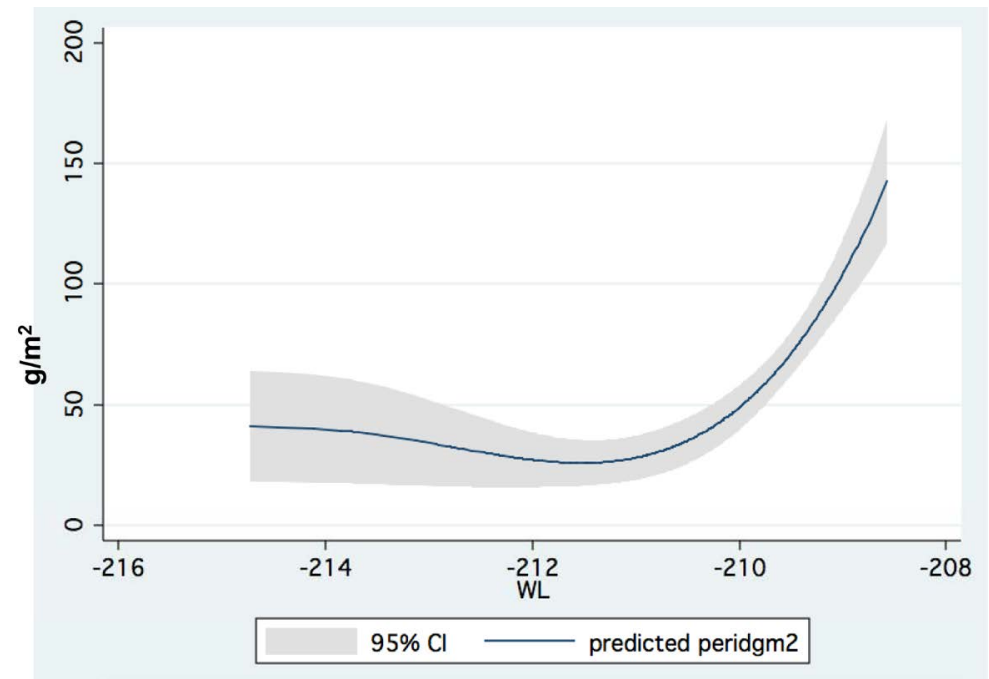

Figure 11. Fractional polynomial prediction $(95 \% \mathrm{CI})$ of pyrrhophyta $\left(\mathrm{g} \cdot \mathrm{m}^{2}\right)$ vs. Kinneret WL (monthly means).

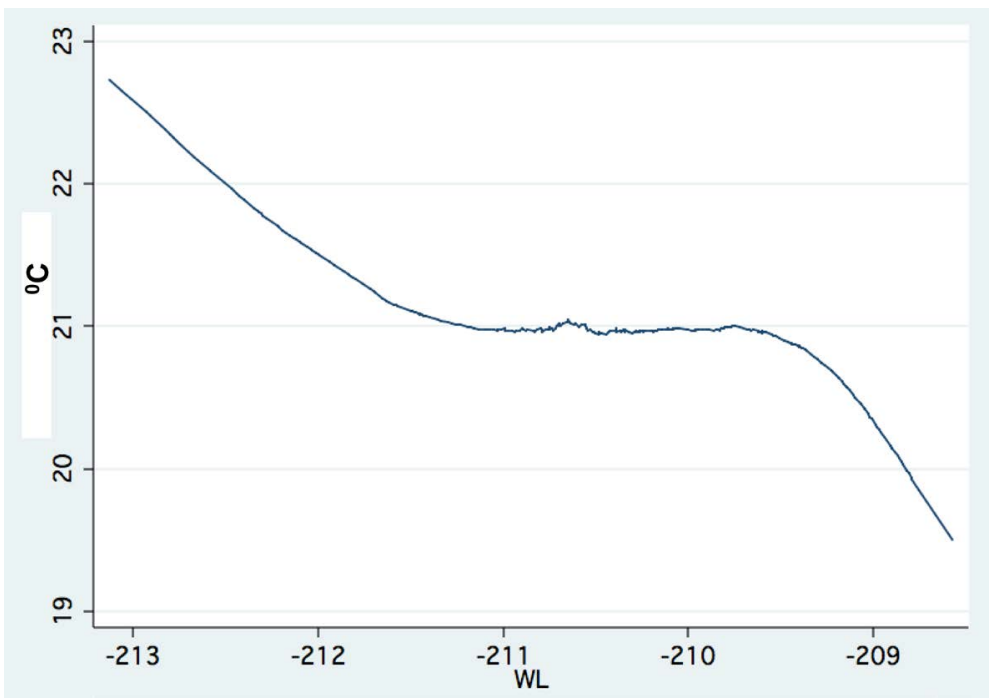

Figure 12. Trend of changes (LOWESS) of averaged epilimnion temperature vs. Kinneret WL (monthly means).

pattern of air temperature changes in Hula Valley, located northern to the Kinneret. It was suggested that in the Hula Valley changes are due to fluctuations of Albedo values resulted in by Land Use modifications in the Hula Valley. Increasing of epilimnetic heat load in Lake Kinneret occur because of consecutive events: WL decline, reduction of the surface water area, and reduction of the epilimnion volume. The ratio between radiation and reflectance of solar energy (Albedo) from water surface (app. 5\%) is the same in both high and low WL. Nevertheless, change of heat capacities emerged from dimensions (surface area and epilimnetic volume) reduction. The decline of Kinneret water level was followed by diminishing of water surface area which lowered total capacity of evaporation induced cooling impact, even so, heat capacity was enhanced. WL decline accompanied by surface reduction has created two factors of heat enhancement: 1) reduction of cooling effect by smaller capacity of evaporation; and 2) lower Albedo total heat addition. Those two factors probably caused an elevation of epilimnetic temperatures. If low WL is a continual case, elevated heat capacity is accumulated. To understand how WL decline contribute to the increase of epilimnetic temperature the following computation is presented:

Berman (1976) Stanhill and Neuman (1978), and Serruya (1978), documented annual averaged incident radiation (solar plus sky) for the Kinneret region as $15.1 \times 10^{6} \mathrm{~J} \cdot \mathrm{m}^{-2} \mathrm{~d}^{-1}$. 
Albedo value for water covered surface is consider as $5 \%$.

Lake water surface at altitude of $209 \mathrm{mbsl}$ and at $214 \mathrm{mbsl}$ is $169.5 \mathrm{~km}^{2}$ and $159.2 \mathrm{~km}^{2}$ respectively $\left(10.3 \mathrm{~km}{ }^{2}\right.$ $=6.1 \%$ reduction).

Epilimnion volume at $209 \mathrm{mbsl}$ is $3184 \times 10^{6} \mathrm{~m}^{3}$ (thermocline depth $22 \mathrm{~m}$ ) and at $214 \mathrm{mbsl}-2258 \times 10^{6} \mathrm{~m}^{3}$ (thermocline depth $16 \mathrm{~m}$ ) [5].

Annual total solar and sky radiation on the entire surface of lake water is $949 \times 10^{15} \mathrm{~J}$ and $892 \times 10^{15} \mathrm{~J}$ for 209 and 214 mbsl respectively.

If reflectance of 5\% (Albedo) is subtracted from incident radiation, annual absorbance is $9020 \times 10^{14} \mathrm{~J}$ and $8470 \times 10^{14} \mathrm{~J}$ for 209 and $214 \mathrm{WL}$ altitude respectively.

Each $\mathrm{m}^{3}$ of the epilimnion absorb annually an additional 2.833 and $3.751 \times 10^{14} \mathrm{~J}$ per $\mathrm{m}^{3}$ at 209 and $214 \mathrm{WL}$ altitude respectively.

The increase of heat absorbance from 2.833 to $3.751 \times 10^{14} \mathrm{~J}$ per $\mathrm{m}^{3}$ represent additional heat capacity of $32.4 \%$ per year. Consequently, WL decline by itself enhance additional heat load to the epilimnion of Lake Kinneret.

\subsection{Nutrient Dynamics}

Undoubtedly the volume of the hypolimnion is significantly $\left(r^{2}=0.462\right)$ reduced but volume of the epilimnion is just slightly become smaller when WL is decline from 209 to $214 \mathrm{mbsl}$. Even if the rate of biological activities in the epilimnion does not modified, their wastes (plankton mortality, fish and zooplankton excretion, etc.) are settled into a smaller volume of the hypolimnion. Consequently, the concentration of nutrients $\left(\mathrm{H}_{2} \mathrm{~S}, \mathrm{NH}_{4}, \mathrm{CO}_{2}\right.$, etc.) together with un-aerobic microbial products significantly increased $\left(\mathrm{H}_{2} \mathrm{~S}: r^{2}=0.582, \mathrm{NH}_{4}: r^{2}=0.401\right.$; $\mathrm{TP}$ : $r^{2}=0.409$; data is not given here). Moreover, biological activities are probably enhanced as a result of the epilimnetic temperature increase resulted by WL decline. Recent report of The Kinneret Limnological Laboratory [5] published information about the negligible upward transfer of Phosphorus. Data presented in this paper confirm that the period of low WL, later than 1993, is characterized by improvement of epilimnetic water quality in terms of lower nutrient concentrations.

\subsection{Phytoplankton Changes}

Serruya \& Pollingher [6] documented that the replacement of non-grazed Peridinium having high C:P ratio by the actively grazed diatoms and green algae having low C:P ratio led to a substantial decrease of algal standing crop in Lake Kinneret. Dominance of diatoms, chlorophytes and cyanophytes was recorded. Nevertheless, report about change of algal assemblages as a result of 17 meters WL decline in Lake Sivan (Armenia) indicated doubling values of algal biomass. The dominance of diatoms and Anabaena sp. in Lake Sivan was documented. The overall response to WL decline in Lake Kinneret was the opposite to Lake Sivan: Increase of algal biomass and eutrophication in Lake Sivan and decrease of algal biomass and oligotrophism in Lake Kinneret. Low WL conditions in Lake Kinneret enhanced the increase of the biomass of Cyanobacteria, Diatoms, and Chlorophyta and obviously their portion (\%) in the assemblages (Table 8). The biomass of the Peridinium which was dominant under high WL was almost eliminated from the Kinneret Phytoplankton community when WL declined and rarely flourished after heavy rainy seasons. On the other hand, the chlorophyll concentration was declined as a result of total algal biomass decline which accompanied the reduction of nutrient concentrations in the epilimnion. The prominent change of N/P ratio in the epilimnion was probably the major reason for the proliferation of Cyanobacteria and the decline of Peridinium. Peridinium is a well known $\mathrm{N}$ limited algae and $\mathrm{N}_{2}$ fixers Cyanobacteria are P limited. The low WL conditions in Lake Kinneret were therefore highly favored by Cyanobacteria. The biomass enhancement of Diatoms and Chlorophyta is probably due to the high level of epilimnetic bioavailable phosphorus. Because of low content of intracellular $\mathrm{N}$ in nano-planktonic algae (especially diatoms and chlorophytes), the preferred food for grazing zooplankton, higher biomass was grazed in order to cover demands for Nitrogen supply [7]. The result of this change was enhanced supply of recycled P in the system.

\subsection{Zooplankton}

The zooplankton biomass density $\left(\mathrm{g} / \mathrm{m}^{2}\right)$ data presented in Table 4, Table 5 and Figure 7, Figure 8 indicates similarity of Total zooplankton, Copepoda, Cladocera, Rotifera, Herbivorous Zooplankton (including herbivorous copepods, cladocerans and rotifers) predator copepods and herbivorous copepods. The top-down predation 
Table 8. Changes of Epilimnetic characteristics affected by WL decline.

\begin{tabular}{cc}
\hline Parameter & Low WL characterization \\
\hline Nemperature & Increase \\
Phosphorus & Low \\
\%Peridinium & High \\
\%Cyanobacteria & Low \\
\%Chlorophyta & High \\
\%Diatoms & High \\
Total phytoplankton & High \\
Zooplankton & Low \\
Water quality: WO toxic Cyanobacteria & Low \\
\hline W & Low \\
\hline With; wO = without) & High \\
\hline
\end{tabular}

impact of zooplnktivorous fish, (bleaks) on zooplankton was previously discussed [2]. Due to its very low market value fishery of bleaks was abandon and consequently its stock in the lake was flourished. Bleak stock size is related to fishery and much less to WL fluctuations with two exceptional winters occur in 1992 and 2002 when WL increase rate was high and Bleak population flourished [2]-[4]. Nevertheless, metabolic parameters of zooplankton (Table 7) indicates decline of feeding efficiencies of all zooplankters at high temperatures. The biomass density of zooplankton, and especially herbivorous animals which create $>80 \%$ of the total biomass, is highly affected by the availability of food resources, mostly, nano-planktonic Chlorophyta and Diatoms. WL decline that was accompanied by increase of temperature caused reduction of zooplankton biomass [8] which was not confounded by elevation of chlorophytes and diatoms biomass. The increase of chlorophytes and diatoms is due to increase of bioavailable Phosphorus (TDP) (Table 3). It is suggested that warmer epilimnion is an advantage for the fishery and biology of the tropical originated fish, Sarotherodon galilaeus. This fish has a high commercial and ecological values but temperatures $<12^{\circ} \mathrm{C}$ are un-tolerable and $>21^{\circ} \mathrm{C}$ are favored by this fish.

\section{Conclusions}

The impact of WL decline on the epilimnion of Lake Kinneret is summarized in Table 8.

\section{Conclusive Remark}

This paper should not be considered as a recommendation to decline WL in Lake Kinneret and high WL is also not ultimately preferred. The paper is aimed at an attempt to consider provisional WL decline resulted by external constrains as an acceptable temporary option.

\section{References}

[1] Gvirtzman, H. (2002) Chapter 3: Lake Kinneret. In: Israel Water Resources, Yad Ben-Zvi, Jerusalem, 33-60.

[2] Gophen, M. (2004) Chapter: Hydrology and Management of Lake Kinneret Aimed at Water Quality Protection. Chapter: Water Utilization in Semi-Arid Zone, The Hula Valley (Israel): Pollutant Removal, Agriculture and Ecotourism Management. In: Water in the Middle East and in North Africa: Resources, Protection, and Management. SpringerVerlag, Berlin. http://dx.doi.org/10.1007/978-3-662-10866-6_18

[3] Gophen, M. (2004) Ecohydrological Management of Lake Kinneret: A Case Study. Ecohydrology and Hydrobiology, 4, 397-408.

[4] Gophen, M. (2008) Long Term (1970-2001) Eco-Hydrological Processes in Lake Kinneret and Its Watershed. In: Zereini, H., Ed., Climatic Changes and Water Resources in the Middle East and in North Africa, Springer, Berlin, 
373-402. http://dx.doi.org/10.1007/978-3-540-85047-2_24

[5] LKDB (1970-2008) Annual Reports. Kinneret Limnological Laboratory, Israel Oceanographic and Limnological Research Co. Ltd.

[6] Serruya, C. and Pollingher, U. (1977) Lowering of Water Level and Algal Biomass in Lake Kinneret. Hydrobiologia, 54, 73-80. http://dx.doi.org/10.1007/BF00018773

[7] Gophen, M. (2011) The Cladoceran Trophic Status in the Nitrogen Limited Ecosystem of Lake Kinneret (Israel). Journal of Environmental Biology, 32, 455-462.

[8] Gophen, M. (2013) The Impact of Temperature Elevation on the Decline of Cyclopoid Population in Lake Kinneret (Israel). The Journal of Ecology, 107, 223-239.

[9] Gophen, M. and Azoulay, B. (2002) The Trophic Status of Zooplankton Communities in Lake Kinneret (Israel). Verhandlungen der Internationalen Vereinigung fur Theoretische und Angewandte Limnologie, 28, 836-839. 
Scientific Research Publishing (SCIRP) is one of the largest Open Access journal publishers. It is currently publishing more than 200 open access, online, peer-reviewed journals covering a wide range of academic disciplines. SCIRP serves the worldwide academic communities and contributes to the progress and application of science with its publication.

Other selected journals from SCIRP are listed as below. Submit your manuscript to us via either submit@scirp.org or Online Submission Portal.
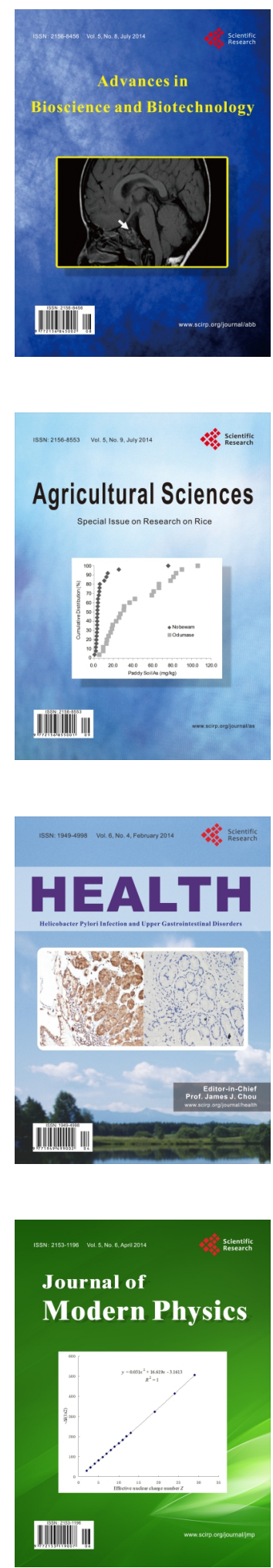
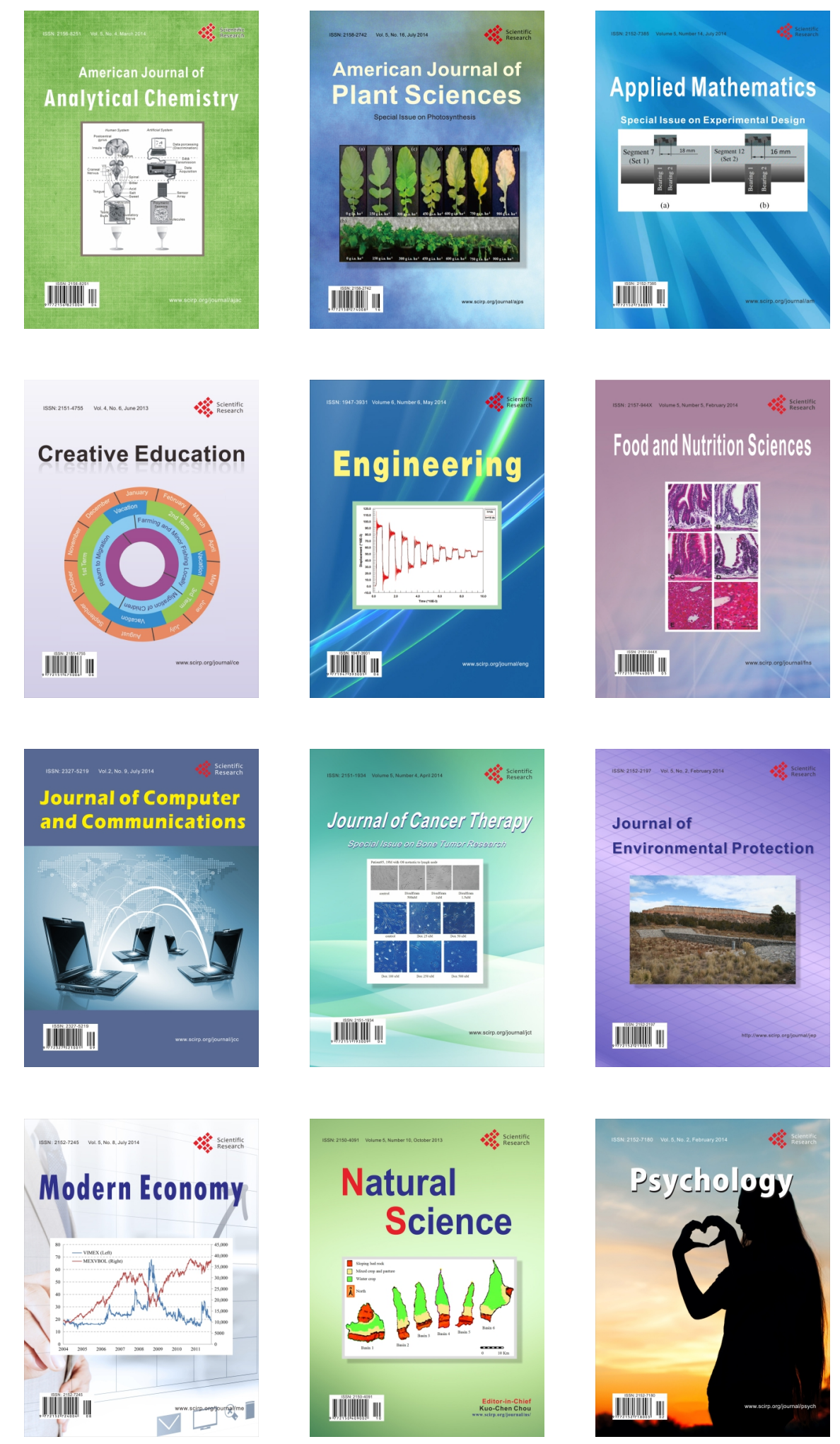